\title{
Marker assisted selection of heifers improved milk somatic cell count compared to selection on conventional pedigree breeding values
}

\begin{abstract}
Although mastitis in cattle is an important factor for dairy economy and animal welfare and although udder health parameters have a substantial genetic variability, in many countries there is little or no improvement of udder health in the conventional commercial breeding programs. Strategies implementing information about Quantitative trait loci (QTL) via genetic marker information seem to offer new prospects to improve this situation. In a proof-of-principle approach, we show that selection of German Holstein heifers prior to first calving based on marker information regarding a confirmed QTL affecting somatic cell score (SCS) on bovine chromosome 18 (BTA18) (MAS strategy) indeed enabled prediction of halfsibs with a high (q) or a low (Q) number of somatic cells in milk already early in the first lactation. Compared to a strategy relying on conventional breeding values only (CON strategy), selection including marker information resulted in a stronger discrimination between and a higher uniformity within the MAS-Q and -q groups compared to the CON-Q and q groups selected by conventional selection strategies. The selected heifers, which are clinically unaffected, however genetically different in their capacity of mammary gland protection against pathogens, will serve as tools for a comprehensive expression analysis to highlight molecular processes underlying a different genetic predisposition to mastitis susceptibility. Thus, functional mechanisms resulting in a decreased susceptibility of the Q individuals can be identified to further improve selection on udder health in cattle.
\end{abstract}

Key Words: mastitis, cattle, QTL, somatic cell score, marker assisted selection

\section{Zusammenfassung}

Titel der Arbeit: Markergestützte Selektion von Jungrindern auf den somatischen Zellgehalt in der Milch im Vergleich zur Selektion auf der Basis von konventionellen Pedigree-Zuchtwerten

Obwohl die Mastitis des Rindes ein wichtiger Faktor für die Ökonomie der Milcherzeugung und das Wohlbefinden der Tiere ist und obwohl außerdem Parameter der Eutergesundheit eine erhebliche genetische Variabilität aufweisen, wurde in Bezug auf Eutergesundheit in vielen Ländern mittels konventioneller Züchtungsmethoden nur wenig oder kein Fortschritt in kommerziellen Zuchtprogrammen erzielt. Strategien, die Informationen über Quantitative trait loci (QTL) mittels genetischer Marker einbeziehen, eröffnen hier neue Perspektiven. In einem Anwendungsbeispiel zeigen wir, dass die Selektion von Deutschen Holstein Färsen vor der ersten Kalbung anhand von Markerinformationen über einen bestätigten QTL mit Effekt auf den somatischen Zellgehalt in der Milch auf dem Rinderchromosom 18 (BTA18) (MAS-Strategie) in der Tat die Vorhersage von Halbgeschwistern mit jeweils hohem (q) oder niedrigem (Q) somatischem Zellgehalt bereits früh in der ersten Laktation ermöglichte. Im Vergleich mit einer Standardselektionsstrategie, die ausschließlich konventionelle Zuchtwerte verwendete (CON-Strategie), ergab die Einbeziehung von Markerinformationen eine stärkere Diskriminierung zwischen und eine größere Einheitlichkeit innerhalb der MAS-Q und -q Gruppen im Vergleich mit den konventionell selektierten Gruppen CON-Q und -q. Die ausgewählten Färsen, die nicht klinisch erkrankt sind, sich jedoch in ihrer Kapazität zum Schutz der Milchdrüse gegen Pathogene genetisch unterscheiden, werden als Ausgangspunkt für eine umfassende Expressionsanalyse dienen, um Unterschiede in der Genexpression vor klinischer Infektion herauszustellen. Auf diese Weise können Mechanismen, die zu einer geringeren Anfälligkeit von Q-Tieren gegenüber klinischer Mastitis führen, identifiziert werden, was dann im Rahmen der Selektion für eine Verbesserung der Eutergesundheit genutzt werden kann.

Schlüsselwörter: Mastitis, Rind, QTL, somatischer Zellgehalt, markergestützte Selektion 


\section{Introduction}

Mastitis in cattle is an important factor for animal welfare and economy in milk production, because it accounts for a substantial part of the economic impact of all health disorders (33\%) amounting up to 80 - $180 € /$ cow-year in Western European production schemes (SEEGERS et al., 2003; KOSSAIBATI and ESSLEMONT, 1997). This is the result of increased costs for mastitis control (mastitis treatment, culling of affected cows) as well as decreased income due to losses in production (up to $12 \%$ long-term losses in production depending on the date of infection and pathogen HAGNESTAM et al., 2007). In a survey within large German dairy farms, HINRICHS et al. (2006) found udder disease frequencies of almost 50\%. In spite of its substantial role in dairy economy, there is little genetic improvement regarding udder health in commercial breeding programs (VIT annual report 2006, http://www.vit.de/Jahresbericht_des_VIT.html). Selection on decreased mastitis incidence is hampered by its low heritability $\left(\mathrm{h}^{2}=0.02-0.04\right.$, RUPP \& BOICHARD, 2003), unfavourable correlations to milk performance traits and lack of direct mastitis recording in most countries. Nevertheless, selection experiments (HERINGSTAD et al., 2007) as well as a number of QTL mapping studies (HOLMBERG and ANDERSSON-EKLUND, 2004; KLUNGLAND et al., 2001; KÜHN et al., 2003; SCHULMAN et al., 2004) indicated a strong genetic background of udder health. Genetic markers in established QTL regions enable calculation of marker assisted breeding values that may serve to identify individuals with desirable or undesirable genetic disposition regarding the trait of interest. These marker assisted predictions may improve the current selection based on phenotypic information only (KALM, 2002). In recent experiments, we had identified a confirmed QTL for somatic cell score (SCS), an indicator of udder health and strongly correlated to mastitis incidence in the German Holstein population ( $\mathrm{r}_{\mathrm{g}}=0.84$; HINRICHS et al., 2005) on bovine chromosome 18 (BTA18) in the German Holstein population (KÜHN et al., 2003; XU et al., 2006). In a selection experiment, taking advantage of the generated information on QTL position and marker genotypes, we present a successful proof-of-principle for the efficiency of a marker assisted selection approach on SCS in halfsibs and compared the results to a concurrent conventional breeding approach.

\section{Animals}

\section{Materials and Methods}

Selection of heifers was performed on the total data set from the German Holstein production population comprising heifers born between February and September 2003, which were sired for first parturition in a time interval of six weeks between December 2004 and February 2005. Further requirement for initial selection was a full three generation pedigree including performance traits.

Starting from this large pool of heifers, two selection strategies for SCS were applied (Figure). Strategy CON (conventional selection) exclusively considered relative estimated breeding values for SCS (RZS) estimated in the routine breeding evaluation (VIT, Verden; www.vit.de). RZS represent the reverse of the SCS EBV to indicate undesirable proofs with values below 100. The scale of the RZS is standardised to a mean of 100 and a genetic standard deviation of 12 points. Thus, high RZS indicate a genetic potential for a low somatic cell count in milk, whereas a low RZS stands for a high number of somatic cells in milk. Strategy CON comprised one progeny group 
originating from sires with extremely high (group "CON-Q”) or extremely low (group "CON-q") RZS, respectively. Furthermore, dam sires were required to show the same direction for RZS as the respective sires, and dams themselves had to have a relative breeding value for SCS at least equal to their sire.

Selection in the CON groups also considered information on milk flow of the sire and maternal grandsire to avoid undesirable low milk flow in the CON-Q group due to the established genetic correlation between milk flow and SCS (RUPP and BOICHARD, 2003). Thus, we excluded daughters from sires with extremely negative (CON-Q group) or extremely positive (CON-q group) breeding values for milk flow.

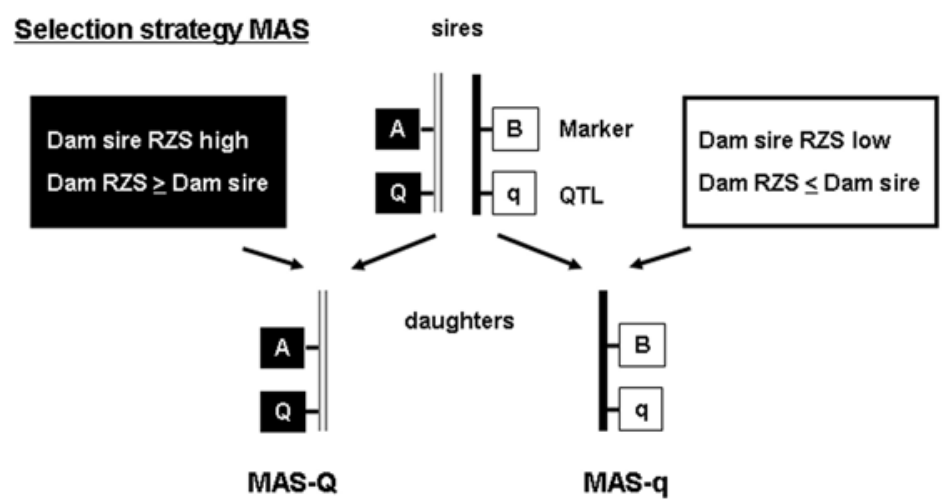

Selection strategy CON

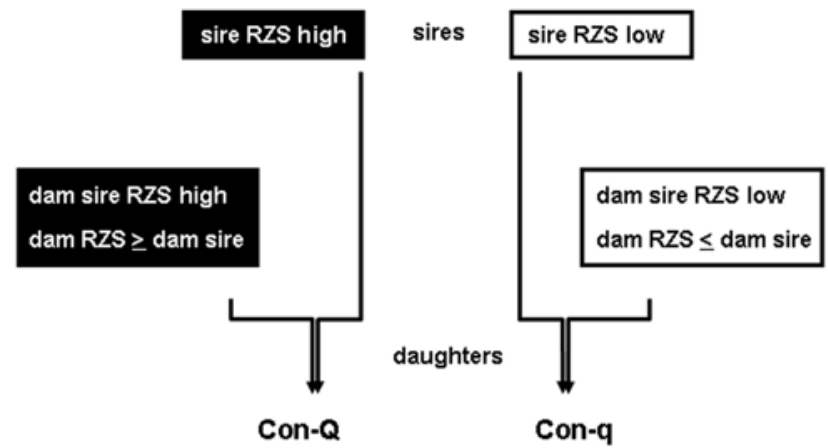

Figure: Selection strategies for selecting heifers for high and low genetic potential regarding milk somatic cell count. RZS: Relative EBV for somatic cell score (SCS); MAS: selection strategy integrating marker assisted information; CON: selection strategy considering conventional breeding values (Selektionsstrategien für die Auswahl von Färsen mit hohem und geringem genetischen Potential hinsichtlich somatischen Zellgehalts in der Milch. RZS: Relativzuchtwert für den Somatischen Cell Score (SCS); MAS: Selektionsstrategie unter Einbeziehung von Markerinformationen; CON: Selektionsstrategie auf der Basis von konventionellen Zuchtwerten)

Strategy MAS included marker information for selection. Three sires were selected from the German Holstein population. They had an RZS close to the average of the sire population, but displayed a difference of at least 1/3 $s_{a}$ in their MA-BLUP (Marker assisted best linear unbiased prediction) breeding value for SCS at their alternative chromosomes in the telomeric region of BTA18. MA-BLUP calculation was performed essentially according to FERNANDO and GROSSMAN (1989) merging 
pedigree, phenotype and genotyping data from the German Holstein population at the central data base at the VIT (WILKENS et al., 2006). The telomeric region had previously been shown to harbour a confirmed QTL affecting somatic cell score (KÜHN et al., 2003; XU et al., 2006). The large differences in alternative sire haplotype effects were taken as indication that the respective sires were presumably heterozygous at the QTL affecting SCS on BTA18. Daughters of the three sires preselected to fulfil the requirements regarding age and time of parturition (see above) as well as their dams (when available) were genotyped for five microsatellite markers (BM7109, ILSTS002, BMS2639, BM2078, TGLA227) as described in XU et al. (2006). From the genotypes of daughter group most likely paternal haplotypes were calculated according to WEIKARD et al. (2005) assuming the marker order in XU et al. (2006). Information on marker-QTL allele linkage phase from the MA-BLUP evaluation was used to assign QTL alleles to the respective paternal marker haplotypes. After the inherited paternal marker haplotype (and thus indirectly the inherited paternal QTL allele) of a heifer was concluded, heifers were assigned to the groups "MAS-Q" (inheriting the SCS decreasing paternal chromosomal region) and "MAS-q" (inheriting the SCS increasing paternal chromosomal region) according to the marker haplotype (and presumable QTL allele) they inherited from the sire.

All 28 heifers selected (CON-Q: 10, CON-q: 7, MAS-Q: 6, MAS-q: 5) were born and raised on ordinary dairy farms, which were distributed over 11 regions in Germany. The heifers were collected at the Research Institute for the Biology of Farm Animals, Dummerstorf (FBN), in August 2005, where they were kept in a free stall barn in one group under identical environmental conditions regarding housing (saw dust bedding), feeding (a total mixed ration equivalent for $25 \mathrm{~kg}$ milk plus $1 \mathrm{~kg}$ concentrate per $\mathrm{kg}$ milk) and milking regime (tandem milking parlour with automated machine takeoff). All veterinary treatments as well as observations of milk leakage between milking times and specific behaviour (anxiety, resistance to milking) were scored for each individual.

\section{Phenotypes}

The somatic cell count of the non-experimental cows in the dairy herd at the FBN was routinely below $100,000 / \mathrm{ml}$ indicating a high management level regarding udder health. All cows including the heifers from our project were milked two times a day in a $12 \mathrm{~h}$ interval. Milk performance and milk flow were recorded automatically for each milking. Milk components and somatic cell count were measured weakly at the local Landeskontrollverband (LKV) using standard technology. At parturition and in weekly intervals body weight and subcutaneous fat (by ultrasonic measurement) were recorded. Udder conformation traits were scored on a scale from 1 to 9 according to routine conformation scoring (www.vit.de) in week 6 after parturition. At day 42 of lactation, milk samples from individual quarters were collected for microbiological investigation. The individuals were slaughtered at day 42 and a post mortem investigation of the udder and the carcass were performed. SCS was calculated according to SHOOK and SCHUTZ, 1994. Energy corrected milk (ECM) was calculated according to KIRCHGESSNER (1997):

$E C M=\frac{0.37 * F \%+0.21 * P \%+0.95}{3.1} * M Y$, where $\mathrm{F} \%$ is the milk fat percentage, $\mathrm{P} \%$ in the milk protein percentage (as determined by routine milk recording at the last test 
before slaughter), and MY is the average daily milk yield at the last seven days before slaughter.

Pairwise t-tests between CON-Q and CON-q and between MAS-Q and MAS-q groups were calculated for pedigree breeding values and for phenotypes regarding milk performance, body weight, somatic cell score, milk flow and udder conformation traits.

\section{Results}

The heifers in group CON-Q descended from four different sires (2-4 heifers/sire), heifers in group CON-q were sired by five different bulls (1-2 heifers/sire). Groups MAS-Q and MAS-q comprised a total of three half sibships, with one sire having three daughters in each group and the other two with one or two offspring in each group.

Corresponding to the selection criterion in the selection strategy CON, the two groups CON-Q and CON-q showed a highly significant difference of 37.9 relative breeding value points for RZS (Table). Heifers in the CON-Q group had lower average and endpoint somatic cell score compared to heifers in the CON-q group. However, the differences between CON-Q and CON-q were not significant. CON-q heifers had a significantly higher average milk flow, which corresponds to the significant difference in pedigree index for average milk flow between the two groups. Furthermore, Con-q heifers were more frequently observed leaking milk between milking times than CON$\mathrm{Q}$ heifers (five heifers out of seven for CON-q, none in the $10 \mathrm{CON}-\mathrm{Q}$-group). In contrast to the CON-groups, the heifers of the MAS-Q and MAS-q groups differed only by 13.4 RZS points, but showed significant differences between groups in the somatic cell score especially for the end point of the test. After six weeks of lactation, the difference between groups amounted to 1.58 SCS points equivalent to 67,000 somatic cells $/ \mathrm{ml}$. In contrast to the CON groups, the difference between Q and q in the MAS groups regarding average milk flow was not statistically significant, which corresponded to the smaller, not significant difference in pedigree index for average milk flow between MAS-Q and MAS-q. In both groups, MAS-Q and MAS-q, two individuals showed leaking of milk between milking times.

The heifers showed a very similar body weight between groups. Regarding milk yield, there was a tendency for a superior milk yield in the CON-q and MAS-q groups compared to their respective Q counterparts, however this was not significant. The same trend was also seen for energy corrected milk. Interestingly, the CON-Q had a significantly higher back fat thickness compared to CON-q and also a tendency for an increased body weight loss, although heifers from this group had a lower milk yield than CON-q. Regarding udder conformation traits, no significant differences between CON-Q and CON-q or between MAS-Q and MAS-q were observed. We had also documented specific behaviour with respect to milking (anxiety, resistance to milking) for each individual, but we did not see differences between groups (data not shown). 
Table

Mean values (S.D.) for $\mathrm{Q}$ and $\mathrm{q}$ groups selected with a conventional (CON) and a marker assisted selection (MAS) strategy (Mittelwerte (Standardabweichung) für Q- und q-Gruppen, die mittels konventioneller (CON) und markergestützter Selektion (MAS) selektiert worden waren)

\begin{tabular}{|c|c|c|c|c|c|c|}
\hline \multirow{2}{*}{$\begin{array}{l}\text { Selection } \\
\text { strategy }\end{array}$} & \multicolumn{3}{|c|}{$\mathrm{CON}$} & \multicolumn{3}{|c|}{ MAS } \\
\hline & $\mathrm{Q}$ & $q$ & $\Delta \mathrm{Q}-\mathrm{q}$ & $\mathrm{Q}$ & $q$ & $\Delta \mathrm{Q}-\mathrm{q}$ \\
\hline $\mathrm{N}$ & 10 & 7 & & 6 & 5 & \\
\hline PI RZS & $\begin{array}{l}121.5 \\
(4.10)\end{array}$ & $\begin{array}{c}83.6 \\
(1.25)\end{array}$ & $37.9^{* * * *}$ & $\begin{array}{l}107.4 \\
(6.17)\end{array}$ & $\begin{array}{c}94 \\
(5.11)\end{array}$ & $13.4^{* *}$ \\
\hline PI RDMG & $\begin{array}{c}96.5 \\
(5.65)\end{array}$ & $\begin{array}{l}109.2 \\
(8.07)\end{array}$ & $-12.7^{* *}$ & $\begin{array}{l}102.0 \\
(4.42)\end{array}$ & $\begin{array}{l}108.1 \\
(7.01)\end{array}$ & -6.1 \\
\hline $\mathrm{BW}_{\mathrm{pp}}$ & $\begin{array}{l}562.4 \\
(40.7)\end{array}$ & $\begin{array}{l}579.9 \\
(67.4)\end{array}$ & -17.5 & $\begin{array}{l}576.4 \\
(25.8)\end{array}$ & $\begin{array}{l}569.0 \\
(60.6)\end{array}$ & 8.4 \\
\hline BWL & $\begin{array}{l}-45.8 \\
(27.2)\end{array}$ & $\begin{array}{l}-37.6 \\
(40.8)\end{array}$ & -8.2 & $\begin{array}{l}-31.0 \\
(15.2)\end{array}$ & $\begin{array}{l}-58.5 \\
(31.8)\end{array}$ & 27.5 \\
\hline $\mathrm{BF}_{\mathrm{pp}}$ & $\begin{array}{c}1.52 \\
(0.15)\end{array}$ & $\begin{array}{c}1.37 \\
(0.11)\end{array}$ & $0.15^{*}$ & $\begin{array}{c}1.36 \\
(0.17)\end{array}$ & $\begin{array}{c}1.48 \\
(0.08)\end{array}$ & -0.12 \\
\hline $\mathrm{BF}_{6 \mathrm{w}}$ & $\begin{array}{c}0.98 \\
(0.18)\end{array}$ & $\begin{array}{c}0.91 \\
(0.13)\end{array}$ & 0.07 & $\begin{array}{c}0.95 \\
(0.19)\end{array}$ & $\begin{array}{c}0.88 \\
(0.15)\end{array}$ & 0.07 \\
\hline$\overline{\mathrm{SCS}_{\mathrm{av}}}$ & $\begin{array}{c}1.87 \\
(1.12) \\
\end{array}$ & $\begin{array}{c}2.61 \\
(1.11)\end{array}$ & -0.74 & $\begin{array}{c}1.76 \\
(0.41) \\
\end{array}$ & $\begin{array}{c}2.94 \\
(1.04) \\
\end{array}$ & $-1.18^{*}$ \\
\hline SCS $_{\text {end }}$ & $\begin{array}{c}1.59 \\
(1.25) \\
\end{array}$ & $\begin{array}{c}2.49 \\
(1.59) \\
\end{array}$ & -0.9 & $\begin{array}{c}1.44 \\
(0.35) \\
\end{array}$ & $\begin{array}{c}3.02 \\
(0.70) \\
\end{array}$ & $-1.58^{* * *}$ \\
\hline DMG & $\begin{array}{c}1.86 \\
(0.44) \\
\end{array}$ & $\begin{array}{c}2.54 \\
(0.66) \\
\end{array}$ & $-0.68^{*}$ & $\begin{array}{c}1.96 \\
(0.60) \\
\end{array}$ & $\begin{array}{c}2.44 \\
(0.52) \\
\end{array}$ & -0.48 \\
\hline $\mathrm{MG}_{\max }$ & $\begin{array}{c}2.96 \\
(0.71)\end{array}$ & $\begin{array}{c}3.74 \\
(0.93)\end{array}$ & -0.78 & $\begin{array}{c}2.83 \\
(0.87)\end{array}$ & $\begin{array}{c}3.79 \\
(1.01)\end{array}$ & -0.96 \\
\hline Milk yield & $\begin{array}{l}27.4 \\
(5.9)\end{array}$ & $\begin{array}{l}31.2 \\
(2.5)\end{array}$ & -3.8 & $\begin{array}{l}26.7 \\
(5.7)\end{array}$ & $\begin{array}{l}29.2 \\
(4.7)\end{array}$ & -2.5 \\
\hline ECM & $\begin{array}{l}30.7 \\
(7.5)\end{array}$ & $\begin{array}{l}31.7 \\
(4.8)\end{array}$ & -1.0 & $\begin{array}{l}28.8 \\
(7.8)\end{array}$ & $\begin{array}{c}30.5 \\
(5.00)\end{array}$ & -1.7 \\
\hline LM & & 5 & & 2 & 2 & \\
\hline FUA & $\begin{array}{c}4.7 \\
(1.3)\end{array}$ & $\begin{array}{c}5.6 \\
(1.9)\end{array}$ & -0.9 & $\begin{array}{c}5.8 \\
(1.5)\end{array}$ & $\begin{array}{c}5.8 \\
(1.3)\end{array}$ & 0 \\
\hline $\mathrm{CL}$ & $\begin{array}{c}5.5 \\
(1.4)\end{array}$ & $\begin{array}{c}5.0 \\
(1.6)\end{array}$ & 0.5 & $\begin{array}{c}5.7 \\
(1.6)\end{array}$ & $\begin{array}{c}5.5 \\
(1.0)\end{array}$ & 0.2 \\
\hline UD & $\begin{array}{c}5.6 \\
(1.4)\end{array}$ & $\begin{array}{c}4.7 \\
(1.4)\end{array}$ & 0.9 & $\begin{array}{c}5.8 \\
(1.5)\end{array}$ & $\begin{array}{c}6.0 \\
(1.4)\end{array}$ & -0.2 \\
\hline TPF & $\begin{array}{c}4.8 \\
(1.0)\end{array}$ & $\begin{array}{c}4.3 \\
(1.6)\end{array}$ & 0.5 & $\begin{array}{c}4.6 \\
(1.4)\end{array}$ & $\begin{array}{c}4.0 \\
(1.4)\end{array}$ & 0.6 \\
\hline TPR & $\begin{array}{c}5.0 \\
(1.5) \\
\end{array}$ & $\begin{array}{c}4.9 \\
(2.0) \\
\end{array}$ & 0.1 & $\begin{array}{c}5.7 \\
(1.2) \\
\end{array}$ & $\begin{array}{c}4.0 \\
(1.2)\end{array}$ & 1.7 \\
\hline $\mathrm{TL}$ & $\begin{array}{c}4.4 \\
(1.6)\end{array}$ & $\begin{array}{c}4.9 \\
(1.5)\end{array}$ & -0.5 & $\begin{array}{c}4.5 \\
(1.2)\end{array}$ & $\begin{array}{c}4.3 \\
(1.7)\end{array}$ & 0.2 \\
\hline
\end{tabular}

PI RZS: pedigree index for RZS $\left(0.5 \mathrm{RZS}_{\text {sire }}+0.5 \mathrm{RZS}_{\mathrm{dam}}\right)$,

PI RDMG: pedigree index for average milk flow per minute $\left(0.5 \mathrm{RDMG}_{\text {sire }}+0.5 \mathrm{RDMG}_{\text {maternal grandsire }}\right)$;

$\mathrm{BW}_{\mathrm{pp}}$ : body weight post partum;

BWL: body weight loss post partum - day 42;

SCS $_{\mathrm{av}}$ : average SCS day 21 - day 42,

$\mathrm{BF}_{\mathrm{pp}}$ : back fat thickness $[\mathrm{cm}]$ post partum;

$\mathrm{BF}_{\text {end }}$ : back fat thickness [cm] day 42;

SCS $_{\text {end }}$ SCS of the last test day before before slaughter (day 42),

DMG: mean value of average milk flow per minute during day 21 - day 42 ,

$\mathrm{MG}_{\max }$ : mean of maximal milk flow during day 21 - day 42,

milk yield: average daily milk yield during day 35 - day 42 ,

ECM: average daily energy corrected milk yield during day 35 - day 42 .

LM: number of individuals observed leaking milk between milking times;

FUA: fore udder attachment;

CL: central ligament;

UD: udder depth;

TPF: front teat placement;

TPR: rear teat placement;

TL: teat length. 
(PI RZS: Pedigree-Index für den RZS (0.5 RZS $\left.\mathrm{Vater}+0.5 \mathrm{RZS}_{\text {Mutter }}\right)$,

PI RDMG: Pedigree-Index für den durchschnittlichen Milchfluss pro Minute (0.5 RMD $\mathrm{Vater}+0.5 \mathrm{RMDG}_{\text {mütterlicher Großvater }}$ );

$\mathrm{BW}_{\mathrm{pp}}$ : Körpergewicht post partum;

BWL: Gewichtsverlust post partum - Tag 42;

$\mathrm{BF}_{\mathrm{pp}}$ : Rückenfettdicke [cm] post partum;

$\mathrm{BF}_{\text {end }}$ : Rückenfettdicke [cm] Tag 42;

SCS $_{\mathrm{av}}$ : arithmetisches Mittel der SCS für den Abschnitt Tag 21 bis Tag 42;

SCS $_{\text {end }}$ : SCS im letzten Probemelken vor der Schlachtung am Tag 42;

DMG: arithmetisches Mittel des durchschnittlichen Milchflusses pro Minute im Abschnitt Tag 21 - Tag 42

$\mathrm{MG}_{\max }$ : arithmetisches Mittel des maximalen Milchflusses pro Minute im Abschnitt Tag 21 - Tag 42;

Milk yield: mittlere tägliche Milchmenge im Abschnitt Tag 35 - Tag 42;

LM: Anzahl der Tiere, für die Milchfluss zwischen den Melkzeiten beobachtet wurde;

FUA: Vordereuteraufhängung;

CL: Zentralband;

UD: Eutertiefe;

TPF: Strichstellung vorne;

TPR: Strichstellung hinten;

TL: Strichlänge.

\section{Discussion}

For both selection strategies (conventional (CON) and marker assisted (MAS) selection), heifers in the Q groups showed the expected decreased somatic cell score compared to the $\mathrm{q}$ individuals. Thus, the favourable genetic potential of the $\mathrm{Q}$ heifers manifested itself already within the first six weeks of lactation. The diversity between $\mathrm{Q}$ and $\mathrm{q}$ groups already increased between the end of the transition period at day 21 and the endpoint of our experiment at day 42, because the difference in SCS at day 42 compared to the mean of the period day $21-42$ was larger for the CON groups as well as for the MAS groups. According to RUPP and BOICHARD (2003), low levels of SCS should be considered as indirect predictors on resistance to mastitis but not as causal effects. This is in line with observations that the role of macrophages, the major cell type in milk from an uninfected udder, for direct pathogen defence is doubtful (RAINARD and RIOLLET, 2006). Thus, the differences in SCS between Q and q groups can be interpreted that genetic mechanisms affecting somatic cell score are in effect already very early in lactation and can be monitored by close examination of SCS. CALUS et al. (2006) described considerable genotype $x$ environment effects in early lactation on somatic cell score with a threefold higher genetic variance in herds with high bulk somatic cell count compared to herds with low bulk somatic cell count. Due to the low bulk somatic cell count in the research herd at the FBN Dummerstorf, into which the selected heifers of the experiment were placed, it can be expected that the differences in SCS between the Q- and q-groups should be even larger in herds with high bulk somatic cell count.

In our experiment, selection on inherited QTL alleles for a specific confirmed QTL affecting SCS on BTA18 proved to be more efficient than conventional selection based on pedigree indices from conventional estimated breeding values. The expected differences in the somatic cell score between the CON-Q and CON-q amounted to 37.9 RZS, which is equivalent to 3.2 genetic standard deviations, and were larger than for MAS-Q and MAS-q (13.4 RZS equivalent to 1.1 standard deviation). Nevertheless, the contrast in SCS between MAS-Q and MAS-q at the end of the test period at day 42 was larger and statistically significant, whereas between the CON-Q and CON-q groups it was smaller and not statistically significant. Furthermore, the variability within group was higher for the CON groups compared to the MAS groups. In the literature, consistent results showed that somatic cell count in the first lactation can serve as a predictor for risk of mastitis in second lactation: cows with lowest SCS always had the lowest risk of clinical mastitis (RUPP et al., 2000). First lactation 
heifers with an SCS $>2$ in the first test day record had an 1.25- 1.38 fold increased risk for mastitis in second lactation compared to heifers with SCS <2 (RUPP et al., 2000). Thus, the MAS-Q heifers in our study could have been expected to be less susceptible to mastitis in following lactations than the MAS-q individuals.

Although we had attempted to limit the effect of milk flow on SCS between Q- and qgroups especially for the CON groups, we observed differences in average milk flow between Q- and q groups, which correspond to the strong genetic correlation between SCS and milk flow ( $\mathrm{r}_{\mathrm{g}}=0.4$, RUPP and BOICHARD, 2003). This affected especially the CON-Q and CON-q group, where the difference in average milk flow was statistically significant and where almost all CON-q individuals showed milk leaking between milking times in contrast to no respective observations for the CON-Q heifers. For the MAS groups, the difference regarding average milk flow was smaller than between the CON groups and observation of milk leaking was equally distributed between MAS-Q and MAS-q groups. Remarkably, the differences in milk flow and milk leaking between groups behave differently to the differences in SCS. It can be speculated that a substantial amount of genetic differentiation between the CON-Q and CON-q groups regarding SCS may be attributed to genes affecting milk flow, whereas genetic differentiation between the MAS-Q and MAS-q groups should be influenced considerably by different mechanisms.

Regarding milk yield and energy corrected milk yield, lack of significant differences between the MAS-Q and MAS-q or between the CON-Q and CON-q groups might be due to the small sample size, especially for milk yield. However, it should be noted that in contrast to clinical mastitis somatic cell score seems to have only a low genetic positive correlation with milk yield (KOIVULA et al., 2005). The same trend can be observed in our data set with q individuals being superior in milk volume.

Initial experiments regarding gene expression analysis indicated a higher power to detect differentially expressed genetic processes for the contrast MAS-Q - MAS-q compared to the conventionally selected groups CON-Q - CON-q. Whereas for the MAS groups differences in immune response, signal transduction, apoptosis, blood formation, cellular transport and homeostasis were highlighted, only differences in signal transduction could be detected for the CON groups (data not shown).

Our experiment is a further confirmation for the QTL for SCS on BTA18, because the halfsib heifers of the MAS-Q and MAS-q inheriting alternative paternal chromosomes for the QTL region on BTA18 displayed significantly different phenotypes for SCS. It has to be pointed out that the MA-BLUP calculation to determine QTL heterozygous sires relied on indirect linkage equilibrium markers, only. For a further increase in efficiency of marker assisted selection, the causal mutations or polymorphisms in close linkage disequilibrium to the QTL for SCS in the German Holstein population are necessary (DEKKERS and VAN DER WERF, 2007). Complementing the fine mapping of the QTL affecting SCS on BTA18 to decrease the number of positional candidate genes, an additional functional approach is necessary due to the high gene density in the chromosomal region investigated. Tissues presumably involved in mechanisms resulting in divergent SCS and susceptibility to mastitis from the heifers of this study will serve to enable a comprehensive microarray expression analysis (CASSAR-MALEK et al., 2007) to highlight differences in gene expression in clinically unaffected cows that are genetically different in their capacity of mammary gland protection against pathogens. 


\section{Acknowledgements}

The authors thank the farmers raising the heifers for their cooperation to provide the heifers included in the project. The financial support of the Förderverein Biotechnologie-Forschung (FBF) and the Federal Ministry of Education and Research (BMBF) within the FUGATO project MAS.net is thankfully acknowledged. The staff of the FBN and our colleagues within the MAS.net project assisted the generation and data sampling within the experiment with expertise and dedication.

\section{References}

CALUS, M.P.L.; JANSS, L.L.G.; VEERKAMP, R.F.:

Genotype by environment interaction for somatic cell score across bulk milk somatic cell count and days in milk. J. Dairy Sci., 89 (2006), 4846-4857

CASSAR-MALEK, I.; PASSELAIGUE, F.; BERNARD, C.; LEGER, J.; HOCQUETTE, J.F.:

Target genes of myostatin loss-of-function in muscles of late bovine fetuses. BMC Genomics, 8 (2007), 63

DEKKERS, J.C.M.; VAN DER WERF, J.H.J.:

Strategies, limitations and difficulties for marker-assisted selection in livestock. In: GULMARES,E.P.; RUANE,J.; SCHERF,B.D.; SONNINO,A.; DARGIE,J.D. ed. Marker Assisted Selection. Current Status and Future Perspectives in Crops, Livestock, Forestry and Fish FAO, Rome, Italy(2007), 167 - 184

FERNANDO, R.L.; GROSSMAN, M.:

Marker Assisted Selection Using Best Linear Unbiased Prediction. Genetics Selection Evolution, 21 (1989), 467-477

HAGNESTAM, C.; EMANUELSON, U.; BERGLUND, B.:

Yield losses associated with clinical mastitis occurring in different weeks of lactation. J. Dairy Sci., 90 (2007), 2260-2270

HERINGSTAD, B.; KLEMETSDAL, G.; STEINE, T.:

Selection responses for disease resistance in two selection experiments with Norwegian red cows. J. Dairy Sci., 90 (2007), 2419-2426

HINRICHS, D.; STAMER, E.; JUNGE, W.; KALM, E.:

Genetic analyses of mastitis data using animal threshold models and genetic correlation with production traits. J. Dairy Sci., 88 (2005), 2260-2268

HINRICHS, D.; STAMER, E.; JUNGE, W.; KALM, E.:

Genetic analysis of several economically important disease traits in German Holstein cows. Arch. Tierz., Dummerstorf 49 (2006), 209-221

HOLMBERG, M.; ANDERSSON-EKLUND, L.:

KALM, E.: Quantitative trait loci affecting health traits in Swedish dairy cattle. J. Dairy Sci., 87 (2004), 2653-2659

Development of cattle breeding strategies in Europe. Arch. Tierz., Dummerstorf 45 (2002), 5-12

KIRCHGESSNER, M.:

Tierernährung. Verlags Union Agrar, Frankfurt a. M., 1997

KLUNGLAND, H.; SABRY, A.; HERINGSTAD, B.; OLSEN, H.G.; GOMEZ-RAYA, L.; VAGE, D.I.; OLSAKER, I.; ODEGARD, J.; KLEMETSDAL, G.; SCHULMAN, N.; VILKKI, J.; RUANE, J.; AASLAND, M.; RONNINGEN, K.; LIEN, S.:

Quantitative trait loci affecting clinical mastitis and somatic cell count in dairy cattle. Mamm. Genome, 12 (2001), 837-842

KOIVULA, M.; MANTYSAARI, E.A.; NEGUSSIE, E.; SERENIUS, T.: Genetic and phenotypic relationships among milk yield and somatic cell count before and after clinical mastitis. J. Dairy Sci., 88 (2005), 827-833

KOSSAIBATI, M.A.; ESSLEMONT, R.J.: The costs of production diseases in dairy herds in England. Veterinary J., 154 (1997), 41-51

KÜHN, C.; BENNEWITZ, J.; REINSCH N.; XU, N.; THOMSEN, H.; LOOFT, C.; BROCKMANN, G.A.; SCHWERIN, M.; WEIMANN, C.; HIENDLEDER, S.; ERHARDT, G.; MEDJUGORAC, I.; FORSTER, M.; BRENIG, B.; REINHARDT, F.; REENTS, R.; RUSS, I.; AVERDUNK, G.; BLUMEL, J.; KALM, E.: Quantitative trait loci mapping of functional traits in the German Holstein cattle population. J. Dairy Sci., 86 (2003), 360-368

RAINARD, P.; RIOLLET, C.:

Innate immunity of the bovine mammary gland. Veterinary Res., 37 (2006), 369-400

RUPP, R.; BEAUDEAU, F.; BOICHARD, D.: 
Relationship between milk somatic-cell counts in the first lactation and clinical mastitis occurrence in the second lactation of French Holstein cows. Prev. Vet. Med., 46 (2000), 99-111

RUPP, R.; BOICHARD, D.:

Genetics of resistance to mastitis in dairy cattle. Veterinary Res., 34 (2003), 671-688

SCHULMAN, N.F.; VIITALA, S.M.; DE KONING, D.J.; VIRTA, J.; MAKI-TANILA, A.; VILKKI, J.H.:

Quantitative trait loci for health traits in Finnish Ayrshire cattle. J. Dairy Sci., 87 (2004), 443-449

SEEGERS, H.; FOURICHON, C.; BEAUDEAU, F.:

Production effects related to mastitis and mastitis economics in dairy cattle herds. Veterinary Res., 34 (2003), 475-491

SHOOK, G.E.; SCHUTZ, M.M.:

Selection on Somatic-Cell Score to Improve Resistance to Mastitis in the United-States. J. Dairy Sci., 77 (1994), 648-658

WEIKARD, R.; KÜHN, C.; GOLDAMMER, T.; FREYER, G.; SCHWERIN, M.:

The bovine PPARGC1A gene: molecular characterization and association of an SNP with variation of milk fat synthesis. Physiol. Genomics, 21 (2005), 1-13

WILKENS, J.; BÜNGER, A.; REINHARDT, F.:

Marker Assisted Selection in German Holsteins - Methods and Application. Proceedings of the 10th QTL-MAS workshop, Salzburg/Austria, 2006

XU, N.Y.; PAUL, S.; BENNEWITZ, J.; REINSCH, N.; THALLER, G.; REINHARD, F.; KUHN, C.;

SCHWERIN, M.; ERHARDT, G.; WEIMANN, C.; THOMSEN, H.; MISHRA, S.; KALM, E.:

Confirmation of quantitative trait loci for somatic cell score on bovine chromosome 18 in the German Holstein. Arch. Tierz., Dummerstorf 49 (2006), 111-119

Received: 2007-10-02

Accepted: 2007-11-19

Authors' addresses

PD Dr. CHRISTA KÜHN*

Res. Unit Molecular Biology

Research Institute for the Biology of Farm Animals (FBN)

Wilhelm-Stahl-Allee 2

18196 DUMMERSTORF / GERMANY

*Corresponding author, kuehn@fbn-dummerstorf.de

Dipl. ing. agr. FRITZ REINHARDT

VIT Verden

27283 VERDEN / GERMANY

Prof. Dr. MANFRED SCHWERIN

Res. Group Functional Genome Analysis

Research Institute for the Biology of Farm Animals

Wilhelm-Stahl-Allee 2

18196 DUMMERSTORF / GERMANY 